НАУ

НАУКОВИЙ ВІСНИК

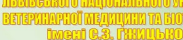

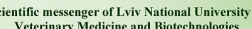

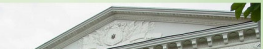

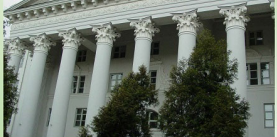

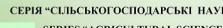

Том 23 № 94 2021
Науковий вісник Дьвівського національного університету ветеринарної медицини та біотехнологій імені С.3. Гжицыкого. Серія: Сільськогосподарські науки

\section{Scientific Messenger of Lviv National University} of Veterinary Medicine and Biotechnologies. Series: Agricultural sciences

ISSN 2519-2698 print ISSN 2707-5834 online doi: 10.32718/nvlvet-a9420

https://nvlvet.com.ua/index.php/agriculture

UDC 636.4

\title{
Globigen Jump Start usage as a replacer for blood plasma in prestarter feed for piglets
}

\author{
T. Y. Prudius, A. V. Gutsol, N. V. Gutsol, O. O. Mysenko \\ Institute of Feed research and Agriculture of Podillya NAAS of Ukraine, Vinnitsia, Ukraine
}

Article info

Received 25.02.2021

Received in revised form 29.03 .2021

Accepted 30.03.2021

Institute of Feed research and Agriculture of Podillya NAAS of Ukraine, pr.Yunosti 16, 21100 Vinnitsia,Ukraine

Tel.: +38-067-322-22-58

E-mail:tarasvet126@gmail.com
Prudius, T. Y., Gutsol, A. V., Gutsol, N. V., \& Mysenko, O. O. (2021). Globigen Jump Start usage as a replacer for blood plasma in prestarter feed for piglets. Scientific Messenger of Lviv National University of Veterinary Medicine and Biotechnologies. Series: Agricultural sciences, 23(94), 111116. doi: $10.32718 /$ nvlvet-a9420

At the current stage of development of the feed industry a lot of feed additives are used for animal feeding. Everyone knows that period of piglet's weaning from sows is always the most critical in the process of pigs' raising. The further result of fattening depends on this period. Therefore, it is important that the diet is adapted to the age of the piglets and the development of their digestive tract. In recent years, either in the world or in Ukraine, the African swine fever (ASF) has become a widespread disease, leading to the decline and closure of a number of pig farms. This prompted the process of safe feed preparation review, and especially the use of a number of make up feed ingredient. The risk group includes porcine blood plasma and its products, which since 2018 have been temporarily banned for use in pig feed in China and a number of European countries. A positive factor in this is the reduction of new outbreaks of this disease. But the lack of blood plasma in prestarter feed for piglets can lead to reduced productivity of piglets due to the lack of animal protein, reduced feed intake, as blood plasma affects the taste of feed. The article presents the results of the feed additive Globigen Jump Start use instead of blood plasma in pre-starter feed for piglets from birth to 42 days of age and in the conditions of industrial inspection. It was found that the replacement of , blood plasma in pre-starter feed for suckling piglets and piglets after weaning for feed additive Globigen Jump Start contributed to an increase in daily intake by $6 \mathrm{~g}$ or by $2.6 \%$. At the same time, the cost of feed per weight gain $1 \mathrm{~kg}$ decreased in the experimental group by $7.89 \%$. As a result of industrial testing when replacing blood plasma with immunological feed additive in the ratio of $42 \mathrm{~kg}$ to $2 \mathrm{~kg}$, respectively, has a significant economic impact on the cost of prestarter feed. This has a positive effect on the piglets' eating and digestibility of feed, which is reflected in better average daily gains, final weight and improved feed conversion and piglet safety.

Key words: immunoglobulins, suckling piglets, weaned piglets, blood plasma, starter and prestarter feed, Globigen Jump Start, productivity.

\section{Використання кормової добавки Глобіген Джамп Старт як замінника плазми крові у престартерному комбікормі для поросят}

\author{
Т. Я. Прудиус, А. В. Гуцол, Н. В. Гуцол, О. О. Мисенко
}

Інституту кормів та сільського господарства Поділля НААН, м. Вінниця, Україна

На даному етапі розвитку комбікормової промисловості в годівлі тварин застосовується чимало кормових добавок. Усім відомо, що період відлучення поросят від свиноматки завжди є найкритичнішим у процесі їх вирощування. Від иього періоду залежить і подальший результат відгодівлі. Тому важливо, щоб раціон був адаптований до віку поросят і розвитку їхнього травного тракту. За останні роки як у світі, так і в Украӥні широко розповсюджене захворювання - африканська чума свиней (АЧС), що призвело до зниження та закриття ряду свиноферм. Це спонукало до перегляду проиесу безпечного приготування кормів, а особливо до використання низки інгредієнтів, з яких складаються корми. До групи ризику належить плазма крові свиней та ї̈ продукти, які з 2018 року було тимчасово заборонено використовувати у кормах для свиней в Китаї та ряді європейських країн. Позитивним 
чинником цуього є зменшення нових спалахів даного захворювання. Але відсутність плазми крові у престартерних кормах для поросят може призвести до зниження продуктивності поросят через відсутність білка тваринного походження, зменшення поїдання корму, оскільки плазма крові впливає на смакові властивості корму. У статті наведено результати використання кормової добавки Глобіген Джамп Старт замість плазми крові в престартерному комбікормі для поросят від народження до 42 доби життя та в умовах виробничої перевірки. Встановлено, ше заміна в престартерному кормі для поросят-сисунів та поросят після відлучення плазми крові на кормову добавку Глобіген Джамп Старт сприяло збільшенню середньодобових приростів на 6 г, або на 2,6\%. При цььму затрати корму на 1 кг приросту зменшувались у дослідній групі на 7,89\%. У результаті виробничої перевірки при заміні плазми крові на імунологічну кормову добавку у співвідношенні 42 кг до 2 кг відповідно має значний економічний вплив на собівартість престартерного корму. Це позитивно впливає на поїдання та засвоюваність корму поросятами, щзо відображено у кращих середньодобових приростах, кінцевій масі та поліпшенні конверсї корму, а також збереженості поросят.

Ключові слова: імуноглобуліни, поросята-сисуни, відлучені поросята, плазма крові, престартерний та стартерний комбікорм, Глобіген Джамп Старт, продуктивність.

\section{Вступ}

Ефективне свинарство - це виробництво свинини 3 оптимальними затратами та мінімальними втратами поголів'я (Pivtorak et al., 2016). Тому співпраця між генетиками, ветеринарами, технологами і науковцями $\epsilon$ тісною та постійною. За останні десятиліття отримання поросят від одної свиноматки на рік збільшилося, також зросла і кількість відлучених поросят. Цьому сприяють як генетичний матеріал, так і специфіка підходу до годівлі тварин (Khalak \& Gutyj, 2020; Khalak et al., 2020; 2021; Roman et al., 2021). Разом 3 тим виникає низка проблем, які призводять до значних втрат у цій галузі. Починаючи із 2014 року в Україні був перший спалах африканської чуми свиней, який і донині наносить сильні економічні збитки господарствам.

Актуальність теми. В зв'язку із цим багато господарств сконцентрували свою увагу на біобезпеку не тільки ферм, а й кормів. Це виявляється в досить критичному ставленні до інгредієнтів кормів, якими годують поросят (Prudyus \& Kyryliv, 2019).

Загальновідомо, що період відлучення поросят від свиноматки завжди $є$ найкритичнішим у процесі вирощування свиней. Від цього періоду залежить подальший результат вирощування і відгодівлі. Проблеми, які виникають під час та після відлучення поросят: слабке поїдання кормів, невеликий приріст, часті діареї тощо призводять до нерівномірного росту поросят у групі й посиленої сприйнятливості до хвороб (Bohdanov \& Rudenko, 2012; Martyshuk et al., 2019; 2020).

Встановлено, що основною причиною описаних проблем $\epsilon$ недостатньо розвинута травна здатність шлунково-кишкового тракту відлучених поросят та їхня імунологічна незрілість, зміна раціону з рідкого на сухий, а крім того, надмірний стрес, який виникає через відлучення від матки і потрапляння в нерідну групу тварин (Hutsol et al., 2013).

У перші тижні після народження поросят зміни в їхньому травленні відбуваються доволі швидко. Важливою особливістю є розвиток здатності до перетравлення білків і жирів, яка постійно збільшується до восьмого тижня життя тварин. Активність лактози, ферменту, який перетравлює молочний цукор, з віком знижується, при цьому одночасно збільшується активність ферментів, які перетравлюють інші цукри. Отож дуже важливо, щоб раціон був адаптований до віку поросят i розвитку їхнього травного тракту (Iulevych et al., 2016).
Для збільшення маси поросяти після відлучення, підвищення споживання ними стартерного корму, а також для боротьби 3 діареєю останнім часом у годівлі широко застосовується плазма крові. Вона $\epsilon$ основним компонентом, який знижує стрес при відлученні, а крім того - альтернативою антибіотикам у кормах тварин (Pentyliuk \& Pentyliuk, 2012).

Плазма крові - кормовий компонент світлобежевого кольору, без запаху і в доступній формі, у вигляді порошку. Вона становить собою неоднорідну суміш функціональних компонентів, яка містить імуноглобуліни, альбуміни, фіброген, ліпіди, фактори росту, біологічно активні пептиди (дефенсин, трансферин), ферменти та інші біологічно активні сполуки. Характеризується високим вмістом білка (75-80\%) i багата на лізин (6,8 \%) високої засвоюваності (84\%). Основними білками плазми крові є альбуміни, а також a-, b- i g-глобуліни (Kempbell, 2011).

Плазма крові використовується насамперед як добавка до сухого корму або замінників молока. При введенні білків плазми крові в раціон поросята значно краще споживають корм і збільшують приріст, при цьому помітно меншає діарей. Свропейські та американські виробники свинини зауважують помітне збільшення приростів, краще поїдання кормів та зростання коефіцієнта їх використання порівняно з поросятами, які одержують корми на традиційних джерелах білка, без плазми крові (Kempbell, 2011).

Практика годівлі поросят показує, що досить широко використовуються корми тваринного походження, які сприяють доброму росту і розвитку поросятсисунів та поросят після відлучення. Це зумовлено високим рівнем перетравності та засвоюваності інгредієнтів. Одним із компонентів престартерних та стартерних кормів $\epsilon$ плазма крові.

Існує думка, що джерелом зараження інфекційними хворобами свиней можуть бути корми тваринного походження, в тому числі й плазма крові.

Тому метою наших досліджень було вивчити ефективність застосування кормової добавки Глобіген Джамп Старт замість плазми крові в престартерному та стартерному комбікормі поросятам від народження до 42 доби їхнього життя та провести виробничу перевірку.

\section{Матеріал і методи досліджень}

Кормова добавка Глобіген Джамп Старт - це функціональний та стандартизований продукт на основі цільного яєчного порошку. Він містить природні іму- 
ноглобуліни (IgY - “імуноглобуліни з жовтка”), змішані з носієм. IgY - це клітини імунної системи птахів, подібні до IgG у ссавців. Вони виконують головну функцію виявлення та нейтралізації шкідливих речовин в організмі. IgY отримуються неінвазивним способом, вони є природними інгредієнтами з яєць. Немає зв'язку з кров'ю та побічними продуктами забою, а отже - і ризику перенесення хвороб тварин.

Глобіген Джамп Старт використовується для підтримки поросят на критичних етапах життя, доки їхній природний імунітет не повністю розвинений. Наукові дані підтвердили, що $\operatorname{IgY}$, присутній у яєчному порошку, здатний підтримувати здоров'я кишечнику та ефективність росту щойно відлучених поросят. Дана кормова добавка має позитивний вплив на імунну систему поросят та їхній ріст і розвиток (Prudyus et al., 2020).

Глобіген Джамп Старт має неоднорідний склад (табл. 1), специфічні імуноглобуліни взяті із курячого жовтка та сухих дріжджів. Це порошок бежевого кольору зі специфічним запахом.

\section{Таблиця 1}

Склад кормової добавки Глобіген Джамп Старт, \%

\begin{tabular}{lc}
\hline Компоненти & Кількість \\
\hline Сирий протеїн & $\geq 40,0$ \\
Сирий жир & $\geq 9,0$ \\
Сира клітковина & $\leq 1,0$ \\
Сира зола & $\leq 8,0$ \\
Натрій & $\leq 0,5$ \\
Лізин & $\geq 3,2$ \\
\hline
\end{tabular}

Добавка має сукупні фармакологічні властивості окремих компонентів, які сприяють поліпшенню росту та розвитку поросят після відлучення, запобігає розвитку діареї та дисбалансу роботи шлунковокишкового тракту.

Специфічні імуноглобуліни IgY захищають від: clostridium perfringens, ротавірусу, трансмісивного гастроентериту, E. coli, неонатальної діареї та діареї при відлученні (К 88, К 99, 987 Р), S. Typhimurium, криптоспорідіозів.

Дослідження проводилися на базі свинокомплексу ТОВ Еко-Міт с. Батятичі Львівської області.

I етап. Дослідження продуктивності поросят при заміні плазми крові кормовою добавкою Глобіген Джамп Старт.

Основним методичним прийомом постановки досліду був прийнятий метод аналогічних груп (Vlizlo et al., 2012). Було сформовано дві групи поросят, по 30 голів у кожній. Перша група була контрольною, яка отримувала раціон із вмістом плазми крові в кількості 42 кг на т комбікорму. Середня маса народжених поросят становила 1,35 кг. До раціону поросятсисунів другої групи вводилася кормова добавка Глобіген Джамп Старт в кількості 2 кг на тонну комбікорму, борошно рибне - 5 кг та соєва олія $-2,5$ кг (табл. 2).

Готовий комбікорм як у контрольній, так і дослідній групі задавали в годівниці. Доступ до корму був вільний. Тривалість досліду 42 доби до моменту переходу із престартерного корму на стартерний.

\section{Таблиця 2}

Склад престартерного комбікорму для поросят, \%

\begin{tabular}{lcc}
\hline \multicolumn{1}{c}{ Показники } & \multicolumn{2}{c}{ Групи } \\
\cline { 2 - 3 } Дентрольна & дослідна \\
\hline Дерть ячмінна & 20,6 & 17,3 \\
Дерть кукурудзяна & 20,0 & 22,0 \\
Дерть пшенична & 17,0 & 17,0 \\
Суха сироватка & 6,0 & 6,0 \\
Плазма крові & 4,2 & - \\
Борошно рибне & - & 5,0 \\
Глобіген Джамп Старт & - & 0,2 \\
Олія соєва & 2,2 & 2,5 \\
Престартер форте & 30,0 & 30,0 \\
(концентрат) & 100 & 100 \\
Разом &
\end{tabular}

\section{Таблиця 3}

Поживна цінність престартерного комбікорму (y 1000 г \%)

\begin{tabular}{|c|c|c|}
\hline \multirow{2}{*}{ Показники } & \multicolumn{2}{|c|}{ Групи } \\
\hline & контрольна & дослідна \\
\hline Енергія загальна, Ккал/кг & 2559,5 & 2554,7 \\
\hline Енергія метаболічна, Ккал/кг & 13,8 & 13,7 \\
\hline Сирий протеїн & 19,42 & 19,57 \\
\hline Сирий жир & 5,06 & 5,87 \\
\hline Сира клітковина & 2,11 & 2,05 \\
\hline Кальцій, \% & 0,74 & 0,88 \\
\hline Фосфор, \% & 0,49 & 0,56 \\
\hline Натрій, \% & 0,47 & 0,28 \\
\hline Лізин, \% & 1,583 & 1,574 \\
\hline Метіонін, \% & 0,546 & 0,612 \\
\hline Треонін, \% & 1,100 & 1,044 \\
\hline Триптофан, \% & 0,337 & 0,319 \\
\hline $\begin{array}{l}\text { Метіонін + цистин (без } \\
\text { добавки), \% }\end{array}$ & 0,932 & 0,915 \\
\hline Лактоза, \% & 5,56 & 5,56 \\
\hline Вітамін А, МО & 20369,3 & 20371,1 \\
\hline Вітамін $\mathrm{D}_{3}, \mathrm{MO}$ & 1992,0 & 1992,0 \\
\hline Вітамін Е, мг/кг & 260,5 & 260,8 \\
\hline Вітамін $\mathrm{K}_{3}$, мг/кг & 2,99 & 2,99 \\
\hline Вітамін $\mathrm{B}_{1}$, мг/кг & 4,92 & 4,77 \\
\hline Вітамін $\mathrm{B}_{2}$, мг/кг & 9,37 & 9,33 \\
\hline Вітамін В $_{5}$, мг/кг & 27,15 & 27,00 \\
\hline Вітамін В6, мг/кг & 7,74 & 7,78 \\
\hline Вітамін В12, мг/кг & 4,98 & 50,92 \\
\hline Біотин, мг/кг & 281,67 & 278,13 \\
\hline Холін, мг/кг & 890,55 & 857,55 \\
\hline Вітамін С, мг/кг & 210,00 & 210,00 \\
\hline Фолієва кислота, мг/кг & 3,28 & 3,26 \\
\hline Магній, \% & 0,08 & 0,09 \\
\hline Хлор,\% & 0,87 & 0,58 \\
\hline Залізо, мг/кг & 173,04 & 182,41 \\
\hline Марганець, мг/кг & 65,49 & 66,14 \\
\hline Мідь, мг/кг & 80,84 & 81,31 \\
\hline Цинк, мг/кг & 148,65 & 155,40 \\
\hline Йод, мг/кг & 1,0 & 1,05 \\
\hline Кобальт, мг/кг & 0,22 & 0,32 \\
\hline Селен, мг/кг & 0,30 & 0,35 \\
\hline
\end{tabular}

II етап. Проведення виробничої перевірки заміни плазми крові кормовою добавкою Глобіген Джамп 
Старт на потужностях цього ж свинокомплексу. Контрольний і дослідний престартерний комбікорм був збалансований за поживними та біологічно активними речовинами і виготовлений на комбікормовому заводі ТОВ “Агролайф корми” с. Давидів Львівського р-ну Львівської обл.

Заміна плазми крові на кормову добавку Глобіген Джамп Старт в престартерному раціоні проводився за допомогою комп'ютерної програми Agrosoft та матричних даних препарату.

Поживну цінність престартерних комбікормів наведено в таблиці 3 .

Престартерний комбікорм за поживною цінністю був повністю забезпечений енергією і протеїном, а також більшістю інших необхідних елементів живлення.

Престартерний комбікорм в маточнику задавали в пластикові мисочки малими порціями протягом світлового дня 35 по 42 добу життя вволю. Після відлучення престартерний корм засипали в бункерні годівниці. Перехід із престартерного на стартерний корм починався на 42 добу життя та тривав протягом чотирьох діб - до 45 доби життя. Зміна корму проходила за такою схемою: 42 доба: 75\% престартера та 25\% стартера;

43 доба: 50 \% престартера та 50 \% стартера;

44 доба: $25 \%$ престартера та $75 \%$ стартера; 45 доба: $100 \%$ стартер.

\section{Таблиця 5}

Показники продуктивності поросят, $\mathrm{M} \pm \mathrm{m}, \mathrm{n}=30$
Склад стартового комбікорму наведено в табл. 4.

\section{Таблиця 4}

Склад стартового комбікорму для поросят, \%

\begin{tabular}{lc}
\hline \multicolumn{1}{c}{ Показники } & Кількість, кг \\
\hline Дерть пшенична & 55,0 \\
Дерть ячмінна & 20,0 \\
Шрот соєвий & 13,3 \\
НР соя & 3,0 \\
Рибне борошно & 2,5 \\
Олія соєва & 1,8 \\
Лізин гідрохлорид & 0,4 \\
Премікс & 4,0 \\
Разом & 100 \\
\hline
\end{tabular}

Стартовий корм, приготовлений на базі потужностей свинокомплексу, задавався у розсипному вигляді в бункерні годівниці з вільним доступом поросятам.

\section{Результати та їх обговорення}

У результаті проведених досліджень встановлено, що застосування специфічних імуноглобулінів у престартерних кормах при заміщенні плазми крові призводить до підвищення збереження поросят, збільшення середньодобових приростів та поліпшення конверсії корму (табл. 5).

\begin{tabular}{|c|c|c|}
\hline \multirow{2}{*}{ Показники } & \multicolumn{2}{|c|}{ Група тварин } \\
\hline & Контрольна & Дослідна \\
\hline Кількість тварин в групі, гол. & 30 & 30 \\
\hline Тривалість періоду, діб & 42 & 42 \\
\hline Жива маса на початок періоду, кг & $1,35 \pm 0,18$ & $1,33 \pm 0,17$ \\
\hline Жива маса на кінець періоду, кг & $10,7 \pm 0,31$ & $10,9 \pm 0,31^{*}$ \\
\hline Абсолютний приріст, кГ & $9,35 \pm 0,25$ & $9,57 \pm 0,26^{*}$ \\
\hline Середньодобовий приріст, г & $222 \pm 1,44$ & $228 \pm 1,43^{*}$ \\
\hline \pm до контролю, кг & - & +6 \\
\hline \pm до контролю, \% & - & $+2,7$ \\
\hline Загальні витрати корму, кг & 210 & 207 \\
\hline Конверсія корму & 0,76 & 0,70 \\
\hline \pm до контролю & - & $-0,06$ \\
\hline \pm до контролю, \% & - & $-7,89$ \\
\hline
\end{tabular}

Аналізуючи показники таблиці 5, можна стверджувати, що застосування кормової добавки Глобіген Джамп Старт як замінника плазми крові у складі престартерного комбікорму для поросят має позитивний ефект - сприяє збільшенню середньодобових приростів на 6 г, а6о на 2,7 \%, при їхньому рівні $222 \pm$ 1,44 г в контрольній і $228 \pm 1,43$ г у дослідній групах. При цьому витрати корму на 1 кг приросту зменшувались у дослідній групі на 7,89\%.

Цікавим $є$ той факт, що тварини дослідної групи використали готового престартерного корму за дослідний період на 1,43 \% менше порівняно 3 контрольною, що також позитивно відобразилося на кращій конверсії корму.
Дана закономірність збереглася при використанні кормової добавки Глобіген Джамп Старт у виробничих умовах, тобто під час виробничої перевірки. Результати наведені у таблиці 6 .

Результати виробничої перевірки показали, що при заміні плазми крові на кормову добавку у співвідношенні 42 кг до 2 кг відповідно має значні переваги. Це позитивно відображається на поїданні та засвоюваності корму поросятами, що відображено у кращих середньодобових приростах, кінцевій масі та поліпшенні конверсії корму. Водночас має місце поліпшення збереженості тварин. Так, технологічний відхід поросят за період вирощування у контрольному варіанті становив $2,7 \%$, а в дослідному - 3,3\%, що на $0,6 \%$ менше. 
Таблиця 6

Результати виробничої перевірки

\begin{tabular}{lcc}
\hline \multicolumn{1}{c}{ Показники } & Контрольна група & Дослідна група \\
\hline Використано престартеру з 2-ї по 44-у добу, кг & 8,19 & 8,93 \\
Використано стартеру з 45-ї по 65-у добу, кг & 26,00 & 21,56 \\
Середня маса тварин на 65-у добу & 23,57 & 24,15 \\
Конверсія корму за дослідний період & 1,55 & 1,35 \\
Смертність, \% & 3,3 & 2,7 \\
\hline
\end{tabular}

Таким чином, одержані дані продуктивності вирощування поросят у виробничих умовах є логічним закінченням досліджень щодо вивчення ефективності використання кормової добавки Глобіген Джамп Старт.

\section{Висновки}

1. Заміна в престартерному кормі для поросятсисунів та стартерному для поросят після відлучення плазми крові на кормову добавку Глобіген Джамп Старт сприяє збільшенню середньодобових приростів на 6 г, а6о на 2,6\%, при їх рівні $222 \pm 1,44$ г в контрольній і $228 \pm 1,43$ г у дослідній групах. При цьому витрати корму на 1 кг приросту зменшуються у дослідній групі на 7,89 \%.

2. У виробничих умовах заміна плазми крові на імунологічну кормову добавку у співвідношенні 42 кг до 2 кг відповідно має також значний позитивний вплив. Це позначається на поїданні та засвоюваності корму поросятами і відображається у кращих середньодобових приростах, кінцевій живій масі та поліпшенні конверсії корму і збереженості поросят.

\section{References}

Bohdanov, H. O., \& Rudenko, Ye. V. (2012). Rekomendatsii $\mathrm{Z}$ normovanoi hodivli svynei. K., Ahrarna nauka, 22-42 (in Ukrainian).

Hutsol, A. V., Hutsol, N. V., Prodan, O. M., \& Hrebeniuk, N. H. (2013). Efektyvnist vykorystannia fermentnykh preparativ matserobatsylinu ta matserazy v hodivli svynei u vyrobnychykh umovakh. Zbirnyk naukovykh prats VNAU, 2(72), 3-7. URL: http://socrates.vsau.org/repository/card.php?lang=uk\& $\mathrm{id}=6805$ (in Ukrainian).

Ibatullina, I. I. (2016). Dovidnyk z povnotsinnoi hodivli silskohospodarskykh tvaryn. Ahrarna nauka, 181-203 (in Ukrainian).

Iulevych, O. I., Lykhach, A. V., \& Dekhtiar, Yu. F.(2016). Otsinka zalezhnosti pokaznykiv rostu pidsysnykh ta vidluchenykh porosiat vid skladu ratsioniv. Naukovyi biuleten IT UAAN. Kharkiv, 115, 258-263. URL: http://nbuv.gov.ua/UJRN/Ntb_2016_115_42 (in Ukrainian).

Kempbell, Dzh. (2011). Bilky plazmy krovi u kharchuvanni porosiat. Prybutkove svynarstvo, 4, 32-34. URL: $\mathrm{http}$ ://profisvine.pigua.info/indexukr.php?id=72 Ukrainian).

Khalak, V. I., \& Gutyj, B. V. (2020). Physicochemical properties and chemical composition of muscle tissue of young pigs of large white breed and their correla- tion with some serum enzymes. Ukrainian Journal of Veterinary and Agricultural Sciences, 3(3), 34-38. doi: 10.32718/ujvas3-3.07.

Khalak, V. I., Hutyi, B. V., Bordun, O. M., \& Ilchenko, M. O. (2021). Riven adaptatsii ta produktyvnist svynomatok riznoi vnutriporodnoi dyferentsiatsii za koefitsiientom intensyvnosti spadu rostu u rannomu ontohenezi. Mizhnarodnyi naukovyi zhurnal "Hraal nauky", 2-3, 218-223. doi: 10.36074/grail-ofscience.02.04.2021.041.

Khalak, V., Gutyj, B., Bordun, O., Horchanok, A., Ilchenko, M., Smyslov, S., Kuzmenko, O., \& Lytvyshchenko, L. (2020). Development and reproductive qualities of sows of different breeds: innovative and traditional methods of assessment. Ukrainian Journal of Ecology, 10(2), 356-360 doi: 10.15421/2020 109.

Khalak, V., Gutyj, B., Bordun, O., Horchanok, A., Ilchenko, M., Smyslov, S., Lytvyshchenko, L., \& Kuzmenko, L. (2020). Large White breed sows. Ukrainian Journal of Ecology, 10(4), 122-126. doi: $10.15421 / 2020178$.

Martyshuk, T. V., Gutyj, B. V., Vishchur, O. I., \& Todoriuk, V. B. (2019). Biochemical indices of piglets blood under the action of feed additive "Butaselmevitplus". Ukrainian Journal of Veterinary and Agricultural Sciences, 2(2), 27-30. doi: 10.32718/ujvas2-2.06.

Martyshuk, T. V., Gutyj, B. V., Zhelavskyi, M. M., Midyk. S. V., Fedorchenko, A. M., Todoriuk, V. B., Nahirniak, T. B., Kisera, Ya. V., Sus, H. V., Chemerys, V. A., Levkivska, N. D., \& Iglitskej, I. I. (2020). Effect of Butaselmevit-Plus on the immune system of piglets during and after weaning. Ukrainian Journal of Ecology, 10(2), 347-352. doi: 10.15421/2020_106.

Pentyliuk, S. Y., \& Pentyliuk, R. S. (2012). Kompleksnoe primenenie biologicheski aktivnih veshhestv $\mathrm{V}$ kormlenii svinej. Efektyvni kormy ta hodivlia, 1, 1821 (in Russian).

Pivtorak, J., Bogdan, I., \& Vinnichenko, G. (2016). Fatlening and meat qualities of swine during feding up with probiotic additives "PROPYGplv" as a part of the ration. Scientific Messenger of LNU of Veterinary Medicine and Biotechnologies. Series: Agricultural Sciences, 18(2), 13-17. doi: 10.15421/nvlvet6703.

Polishchuk, A. A., \& Bulavkina, T. P. (2010). Suchasni kormovi dobavky $\mathrm{v}$ hodivli tvaryn ta ptytsi. Visnyk Poltavskoi derzhavnoi ahrarnoi akademii, 2, 66-69. URL: https://www.pdaa.edu.ua/sites/default/files/ visnyk/2010/02/63.pdf (in Ukrainian).

Prudyus, T. Y., Hutsol, A. V., \& Kyryliv, Y. I. (2020). Efficiency of using the "Globigen Life Start" feed additive in feeding calves. Feeds and Feed Production, 
90, 169-178. doi: 10.31073/kormovyrobnytstvo20209015.

Prudyus, T., \& Kyryliv, Y. (2019). The effectiveness of the use of drugs Globigen Pig Dozer and Globigen Jump Start when growing pigs. Scientific Messenger of LNU of Veterinary Medicine and Biotechnologies. Series: Agricultural Sciences, 21(91), 94-97. doi: 10.32718/nvlvet-a9116.

Roman, L., Sidashova, S., Popova, I., Levchenko, A., Bogach, M., Sklyarov, P., Ulyzko, S., Koreyba, L.,
Kushnir, V., Chornyi, V., \& Gutyj, B. (2021). Lateral profile of the pigs' teat line of different Ukrainian breeds. Ukrainian Journal of Ecology, 11(1), 360-367. doi: 10.15421/2021_53.

Vlizlo, V. V., Fedoruk, R. S., \& Ratych, I. B. (2012). Laboratorni metody doslidzhen ubiolohii, tvarynnytstvi ta veterynarnii medytsyni: dovidnyk. Lviv: SPOLOM (in Ukrainian). 